\title{
Urgences
}

\section{Propriété analogue...}

\section{Claude Gaudreau}

Numéro 15, octobre 1986

Épigraphiques

URI : https://id.erudit.org/iderudit/025331ar

DOI : https://doi.org/10.7202/025331ar

Aller au sommaire du numéro

Éditeur(s)

Urgences

ISSN

0226-9554 (imprimé)

1927-3924 (numérique)

Découvrir la revue

Citer ce document

Gaudreau, C. (1986). Propriété analogue... Urgences, (15), 69-69.

https://doi.org/10.7202/025331ar

Ce document est protégé par la loi sur le droit d'auteur. L'utilisation des services d'Érudit (y compris la reproduction) est assujettie à sa politique d'utilisation que vous pouvez consulter en ligne.

https://apropos.erudit.org/fr/usagers/politique-dutilisation/
Cet article est diffusé et préservé par Érudit.

Érudit est un consortium interuniversitaire sans but lucratif composé de l’Université de Montréal, l'Université Laval et l'Université du Québec à Montréal. Il a pour mission la promotion et la valorisation de la recherche. https://www.erudit.org/fr/ 


\section{Claude Gaudreau}

Les physiciens les expliquent actuellement par le fait que les particules quantons ont des propriétés analogues à la vitesse et à la position, mais plus floues, ne prenant de la consistance qu'à l'occasion d'une mesure.

Suen Ortoli et Jean-Pierre Pharabod: Le cantique des quantiques

Propriété analogue à un château de la Loire, mais plus floue:

\section{Château en Espagne \\ c'est-à-dire partout}

La primera pregunta es: ¿Qué es más macho, un château d'eau ou un autobus jaune?

Une consistance sur mesure la concise stance, $\mathrm{K}$ nonique

L'acte officiel de compaction de l'univers à l'intérieur du quantum action qu'est le concept, ou l'équation

La segunda pregunta: ¿Qué es más macho, une perle rare ou une prêle commune?

Sous la tente le brave soupire:

Et les hanches de mon amante sont comme une vague de superfluide qui parcourt la dune 